Edunomika - Vol. 02, No. 01 (Pebruari 2018)

\title{
PENINGKATAN PEMAHAMAN TENTANG MOTIVASI BELAJAR MELALUI METODE ROLE PLAY PADA SISWA KELAS VII E SEMESTER 1 SMP NEGERI 7 SUKOHARJO TAHUN 2017/2018
}

\author{
Tuhri \\ SMP Negeri 7 Sukoharjo, Jawa Tengah \\ Email:tuhri@gmail.com
}

\begin{abstract}
Abstrak: Penelitian ini bertujuan untuk meningkatkan hasil belajar bimbingan konseling materi peningkatan pemahaman tentang motivasi belajar melalui metode role play pada siswa kelas VII E SMP Negeri 7 Sukoharjo Semester I Tahun Pelajaran 2017/2018. Metode penelitian menggunakan Penelitian Tindakan Kelas yang dilaksanakan dalam dua siklus setiap siklus terdiri dua kali pertemuan, dengan empat tahap penelitian: perencanaan, pelaksanaan, pengamatan dan refleksi. Subjek penelitian ini adalah siswa-siswi kelas VII E SMP Negeri 7 Sukoharjo semester I tahun ajaran 2017/2018. Dengan jumlah 30 siswa. Teknik pengumpulan data yang digunakan adalah observasi, wawancara, tes, dan dokumentasi. Analisis data yang digunakan dalam penelitian ini adalah analisis deskriptif kualitatif. Hasil penelitian ini adalah meningkatkan hasil belajar bimbingan konseling materi peningkatan pemahaman tentang motivasi belajar. Hal ini dibuktikan dengan peningkatan hasil belajar siswa pada siklus I siswa yang berhasil mendapat nilai KKM, yang awalnya 18 siswa (60\%) meningkat menjadi 22 siswa atau 73,33\% atau terdapat peningkatan sebesar 13,33\% dibandingkan kondisi awal. Sedangkan pada siklus II meningkat menjadi 27 siswa yang mendapat nilai di atas KKM atau 90\% atau terdapat peningkatan sebesar 16,67\% dari sebelumnya. Berdasarkan hasil penelitian ini dapat disimpulkan bahwa dengan penerapan metode role play dapat meningkatkan hasil belajar bimbingan konseling materi peningkatan pemahaman tentang motivasi belajar pada siswa kelas VII E SMP Negeri 7 Sukoharjo Semester I Tahun Pelajaran 2017/2018.
\end{abstract}

Kata kunci: hasil belajar, motivasi belajar, role play

\begin{abstract}
This study aims to improve the learning outcomes of counseling materials on improving the understanding of learning motivation through role play method in the students of class VII E Junior High School 7 Sukoharjo Semester I Lesson Year 2017/2018. The research method using Classroom Action Research which is carried out in two cycles each cycle consists of two meetings, with four stages of research: planning, implementation, observation and reflection. The subject of this research is the students of class VII E Junior High School 7 Sukoharjo first semester of academic year 2017/2018. With a total of 30 students. Data collection techniques used are observation, interviews, tests, and documentation. Data analysis used in this research is descriptive qualitative analysis. The results of this study is to improve the learning outcomes of counseling learning materials to improve understanding of learning motivation. This is evidenced by the increase in student learning outcomes in the first cycle of students who successfully got the value of KKM, which initially 18 students (60\%) increased to 22 students or $73.33 \%$ or an increase of $13.33 \%$ compared to the initial conditions. While in the second cycle increased to 27 students who scored above the KKM or $90 \%$ or an increase of 16.67\% from the previous. Based on the results of this study can be concluded that with the application of role play method can improve the learning outcomes of counseling learning materials increase understanding of learning motivation in students of class VII E Junior High School 7 Sukoharjo Semester I Lesson 2017/2018.
\end{abstract}

Keywords: learning outcomes, learning motivation, role play 


\section{PENDAHULUAN}

Konseling adalah hubungan pribadi yang dilakukan secara tatap muka antarab dua orang dalam mana konselor melalui hubungan itu dengan kemampuan-kemampuan khusus yang dimilikinya, menyediakan situasi belajar. Dalam hal ini konseli dibantu untuk memahami diri sendiri, keadaannya sekarang, dan kemungkinan keadaannya masa depan yang dapat ia ciptakan dengan menggunakan potensi yang dimilikinya, demi untuk kesejahteraan pribadi maupun masyarakat. Lebih lanjut konseli dapat belajar bagaimana memecahkan masalah-masalah dan menemukan kebutuhan-kebutuhan yang akan datang. (Tolbert, dalam Prayitno 2004 : 101).

Bimbingan konseling akan lebih efektif jika dilakukan melalui dunia pendidikan formal, sehingga sumber daya manusia akan semakin baik dan terarah. Sumber daya manusia akan jauh lebih mudah ditingkatkan jika melalui proses pendidikan, karena pendidikan merupakan cara terbaik untuk meningkatkan kualitas sumber daya manusia suatu bangsa (Tho'in, 2017: 162). Pendidikan menjadi motor penggerak bagi keberlangsungan sumber daya manusia yang handal suatu negara. Sehingga pendidikan menjadi suatu aspek kehidupan yang sangat mendasar bagi pembangunan bangsa.

Penyelenggaraan pendidikan di sekolah melibatkan guru sebagai pendidik dan siswa sebagai peserta didik. Hal tersebut diwujudkan dengan adanya interaksi belajar mengajar atau proses pembelajaran. Proses pembelajaran yang dilakukan oleh banyak tenaga pendidik saat ini cenderung pada pencapaian target materi kurikulum atau lebih mementingkan pada penghafalan konsep bukan pada pemahaman. Hal ini dapat dilihat dari kegiatan pembelajaran di dalam kelas yang selalu didominasi oleh guru. Dalam penyampaian materi, biasanya guru menggunakanmodel ceramah, di mana siswa hanya duduk, mencatat, dan mendengarkan apa yang disampaikannya dan sedikit peluang bagi siswa untuk bertanya.

Pembelajaran biasanya hanya disampaikan secara konvensional, dimana guru yang berperan aktif, sementara siswa cenderung pasif. Sikap siswa yang pasif dapat mengurangi keterlibatannya dalam mengikuti proses pembelajaran yang dapat mengakibatkan turunnya minat siswa dalam mengikuti proses pembelajaran. Masalah lain yang muncul adalah rendahnya kemampuan sosial antar siswa. Rendahnya rasa sosial ini akan menimbulkan sifat individualisme pada diri siswa. Hal ini sangat tidak baik jika terus menerus ada di dalam diri siswa. Oleh karena itu guru harus berperan aktif untuk menumbuhkan rasa sosial di antara siswa. Karena dengan tingginya kemampuan sosial yang dimiliki, para siswa akan lebih mudah berbaur di dalam lingkungan hidupnya.

Dalam hal lain yang dapat dikatakan masalah adalah kurangnya rasa percaya diri dalam diri siswa untuk mengemukakan pendapat dan berbicara di depan umum. Banyak siswa yang lebih memilih untuk memendam pendapatnya selama proses pembelajaran. Sebagai pengajar, guru harus membantu siswa menggali kepercayaan diri mereka. Karena dengan adanya rasa percaya diri, siswa akan lebih yakin untuk berbicara di hadapan orang.

Hasil belajar siswa sangat dipengaruhi oleh kualitas pembelajaran yang dilaksanakan di sekolah. Salah satu yang menentukan kualitas pembelajaran adalah penggunaan model pembelajaran yang tepat dengan materi yang diajarkan. Pada kenyataannya banyak sekolah 
yang kurang memperlihatkan penggunaan model pembelajaran dalam setiap penampilan mengajar.

Dengan demikian, suasana pembelajaran menjadi tidak kondusif sehingga siswa menjadi pasif. Kenyataan ini berlaku untuk semua mata pelajaran termasuk mata pelajaran Bimbingan dan Konseling (BK). Pentingnya pendidikan Bimbingan dan Konseling karena memiliki beberapa fungsi yang sangat baik, fungsi tersebut adalah: pertama, fungsi pemahaman, yaitu fungsi bimbingan dan konseling membantu konseli agar memiliki pemahaman terhadap dirinya (potensinya) dan lingkungannya (pendidikan, pekerjaan, dan norma agama). Berdasarkan pemahaman ini, konseli diharapkan mampu mengembangkan potensi dirinya secara optimal, dan menyesuaikan dirinya dengan lingkungan secara dinamis dan konstruktif. Kedua, fungsi preventif, yaitu fungsi yang berkaitan dengan upaya konselor untuk senantiasa mengantisipasi berbagai masalah yang mungkin terjadi dan berupaya untuk mencegahnya, supaya tidak dialami oleh konseli. Melalui fungsi ini, konselor memberikan bimbingan kepada konseli tentang cara menghindarkan diri dari perbuatan atau kegiatan yang membahayakan dirinya. Ketiga, fungsi pengembangan, yaitu fungsi bimbingan dan konseling yang sifatnya lebih proaktif dari fungsi-fungsi lainnya. Konselor senantiasa berupaya untuk menciptakan lingkungan belajar yang kondusif, yang memfasilitasi perkembangan konseli. Konselor dan personel Sekolah/Madrasah lainnya secara sinergi sebagai teamwork berkolaborasi atau bekerjasama merencanakan dan melaksanakan program bimbingan secara sistematis dan berkesinambungan dalam upaya membantu konseli mencapai tugas-tugas perkembangannya. Teknik bimbingan yang dapat digunakan disini adalah pelayanan informasi, tutorial, diskusi kelompok atau curah pendapat (brain storming),home room, dan karyawisata. Keempat, fungsi penyembuhan, yaitu fungsi bimbingan dan konseling yang bersifat kuratif. Fungsi ini berkaitan erat dengan upaya pemberian bantuan kepada konseli yang telah mengalami masalah, baik menyangkut aspek pribadi, sosial, belajar, maupun karir. Teknik yang dapat digunakan adalah konseling, dan remedial teaching. Kelima, fungsi penyaluran, yaitu fungsi bimbingan dan konseling dalam membantu konseli memilih kegiatan ekstrakurikuler, jurusan atau program studi, dan memantapkan penguasaan karir atau jabatan yang sesuai dengan minat, bakat, keahlian dan ciri-ciri kepribadian lainnya. Dalam melaksanakan fungsi ini, konselor perlu bekerja sama dengan pendidik lainnya di dalam maupun di luar lembaga pendidikan. Keenam, fungsi adaptasi, yaitu fungsi membantu para pelaksana pendidikan, kepala Sekolah/Madrasah dan staf, konselor, dan guru untuk menyesuaikan program pendidikan terhadap latar belakang pendidikan, minat, kemampuan, dan kebutuhan konseli. Dengan menggunakan informasi yang memadai mengenai konseli, pembimbing/konselor dapat membantu para guru dalam memperlakukan konseli secara tepat, baik dalam memilih dan menyusun materi Sekolah/Madrasah, memilih metode dan proses pembelajaran, maupun menyusun bahan pelajaran sesuai dengan kemampuan dan kecepatan konseli. Ketujuh, fungsi penyesuaian, yaitu fungsi bimbingan dan konseling dalam membantu konseli agar dapat menyesuaikan diri dengan diri dan lingkungannya secara dinamis dan konstruktif. Kedelapan, fungsi perbaikan, yaitu fungsi bimbingan dan konseling untuk membantu konseli sehingga dapat memperbaiki kekeliruan dalam berfikir, berperasaan dan bertindak (berkehendak). Konselor 
melakukan intervensi (memberikan perlakuan) terhadap konseli supaya memiliki pola berfikir yang sehat, rasional dan memiliki perasaan yang tepat sehingga dapat mengantarkan mereka kepada tindakan atau kehendak yang produktif dan normatif. Kesembilan. fungsi fasilitasi, memberikan kemudahan kepada konseli dalam mencapai pertumbuhan dan perkembangan yang optimal, serasi, selaras dan seimbang seluruh aspek dalam diri konseli. Kesepuluh, fungsi pemeliharaan, yaitu fungsi bimbingan dan konseling untuk membantu konseli supaya dapat menjaga diri dan mempertahankan situasi kondusif yang telah tercipta dalam dirinya. Fungsi ini memfasilitasi konseli agar terhindar dari kondisi-kondisi yang akan menyebabkan penurunan produktivitas diri. Pelaksanaan fungsi ini diwujudkan melalui program-program yang menarik, rekreatif dan fakultatif (pilihan) sesuai dengan minat konseli.

Menurut Abu Ahmadi (1991: 1), bahwa bimbingan adalah bantuan yang diberikan kepada individu (peserta didik) agar dengan potensi yang dimiliki mampu mengembangkan diri secara optimal dengan jalan memahami diri, memahami lingkungan, mengatasi hambatan guna menentukan rencana masa depan yang lebih baik. Hal senada juga dikemukakan oleh Prayitno dan Erman Amti (2004: 99), Bimbingan adalah proses pemberian bantuan yang dilakukan oleh orang yang ahli kepada seseorang atau beberapa orang individu, baik anak-anak, remaja, atau orang dewasa; agar orang yang dibimbing dapat mengembangkan kemampuan dirinya sendiri dan mandiri dengan memanfaatkan kekuatan individu dan sarana yang ada dan dapat dikembangkan berdasarkan norma-norma yang berlaku.

Sementara Bimo Walgito (2004: 4-5), mendefinisikan bahwa bimbingan adalah bantuan atau pertolongan yang diberikan kepada individu atau sekumpulan individu dalam menghindari atau mengatasi kesulitan-kesulitan hidupnya, agar individu dapat mencapai kesejahteraan dalam kehidupannya. Chiskolm dalam McDaniel, dalam Prayitno dan Erman Amti (1994: 94), mengungkapkan bahwa bimbingan diadakan dalam rangka membantu setiap individu untuk lebih mengenali berbagai informasi tentang dirinya sendiri.

Upaya peningkatan prestasi belajar siswa tidak terlepas dari berbagai faktor yang mempengaruhinya. Dalam hal ini, diperlukan guru kreatif yang dapat membuat pembelajaran menjadi lebih menarik dan disukai oleh peserta didik. Suasana kelas perlu direncanakan dan dibangun sedemikian rupa dengan menggunakan model atau metode pembelajaran yang tepat agar siswa dapat memperoleh kesempatan untuk berinteraksi satu sama lain sehingga pada gilirannya dapat diperoleh prestasi belajar yang optimal. Untuk itu perlu disadari oleh guru bahwa dalam melaksanakan pembelajaran perlu pula diupayakan pembelajaran yang bersifat membangun dan memberikan pengalaman terhadap materimateri yang diberikan.

Keterbatasan waktu yang tersedia menyebabkan guru mengejar target pencapaian kurikulum memilih jalan yang termudah untuk menginformasikan fakta dan konsep, yaitu melalui model ceramah kemudian latihan soal dan siswa memperhatikan penjelasan guru tanpa melakukan aktivitas sehingga siswa pasif. Guru dalam mengajarkan Bimbingan dan Konseling khususnya sub pokok bahasan peningkatan pemahaman tentang motivasi belajar kepada siswa kurang melibatkan siswa secara aktif dalam interaksi belajar mengajar 
sehingga siswa kurang termotivasi dalam belajar. Guru juga kurang melibatkan lingkungan sebagai media sehingga siswa kurang mengenal lingkungan dan tidak dapat memperoleh pemahaman yang berarti.

Disaat proses belajar mengajar berlangsung, guru kurang menggunakan model pembelajaran yang bervariasi sehingga hal tersebut dapat menyebabkan siswa jenuh dan kurang aktif sehingga hasil belajar tidak meningkat justru turun. Penggunaan berbagai macam model pembelajaran dapat memakan waktu yang lebih lama sementara waktu mengajarnya terbatas. Guru juga jarang sekali menggunakan pendekatan pembelajaran ketika sedang mengajarkan materi bimbingan dan konseling. Terkait belum optimalnya proses pembelajaran bimbingan dan konseling (BK) di kelas VII E Semester I SMP Negeri 7 Sukoharjo maka peneliti berupaya untuk menerapkan metode pembelajaran role play sebagai salah satu alternatif pembelajaran bermakna yang bermuara pada pembelajaran yang aktif, kreatif, efektif dan menyenangkan.

Metode Role Playing adalah suatu cara penguasaan bahan-bahan pelajaran melalui pengembangan imajinasi dan penghayatan siswa. Pengembangan imajinasi dan penghayatan dilakukan siswa dengan memerankannya sebagai tokoh hidup atau benda mati. Permainan ini pada umumnya dilakukan lebih dari satu orang, hal itu bergantung kepada apa yang diperankan.

Pada metode bermain peranan, titik tekanannya terletak pada keterlibatan emosional dan pengamatan indera ke dalam suatu situasi masalah yang secara nyata dihadapi. Murid diperlakukan sebagai subyek pembelajaran, secara aktif melakukan praktik-praktik berbahasa (bertanya dan menjawab) bersama teman-temannya pada situasi tertentu. Belajar efektif dimulai dari lingkungan yang berpusat pada diri murid (Departemen Pendidikan Nasional, 2002). Lebih lanjut prinsip pembelajaran memahami kebebasan berorganisasi, dan menghargai keputusan bersama, murid akan lebih berhasil jika mereka diberi kesempatan memainkan peran dalam bermusyawarah, melakukan pemungutan suara terbanyak dan bersikap mau menerima kekalahan sehingga dengan melakukan berbagai kegiatan tersebut dan secara aktif berpartisipasi, mereka akan lebih mudah menguasai apa yang mereka pelajari (Boediono, 2001). Jadi, dalam pembelajaran murid harus aktif, karena tanpa adanya aktivitas, maka proses pembelajaran tidak mungkin terjadi.

\section{KAJIAN TEORI}

\section{Teori Hasil Belajar Siswa}

Menurut R. Gagne seperti yang dikutip oleh Slameto (2000:78) memberikan dua definisi belajar, yaitu belajar adalah suatu proses untuk memperoleh motivasi dalam pengetahuan, keterampilan, kebiasaan, dan tingkah laku. Belajar adalah penguasaan pengetahuan atau keterampilan yang diperoleh dari instruksi. Menurut Skinner yang dikutip oleh Dimyati dan Mudjiono (2006:93) bahwa belajar merupakan hubungan antara stimulus dan respon yang tercipta melalui proses tingkah laku. M. Sobry Sutikno (2010:35) mengemukakan belajar merupakan suatu proses usaha yang dilakukan oleh seseorang untuk memperoleh suatu perubahan yang baru sebagai hasil pengalamannya sendiri dalam interaksi dengan lingkungannya. 
Berdasarkan beberapa pengertian di atas maka dapat penulis simpulkan bahwa belajar adalah perubahan serta peningkatan kualitas dan kuantitas tingkah laku seseorang di berbagai bidang yang terjadi akibat interaksi terus menerus dengan lingkungannya.

Hasil belajar siswa menurut W. Winkel (2004:82) adalah keberhasilan yang dicapai oleh siswa, yakni prestasi belajar siswa di sekolah yang mewujudkan dalam bentuk angka. Hasil belajar adalah pola-pola perbuatan, nilai-nilai, pengertian-pengertian, sikap-sikap, apresiasi dan keterampilan-keterampilan (Suprijono, 2011:5). Hasil belajar adalah hasil yang dicapai dalam bentuk angka atau skor setelah tes hasil belajar pada setiap akhir pembelajaran (Dimyati dan Mujiono, 2006:24).

Definisi di atas dapat disimpulkan bahwa hasil belajar adalah prestasi belajar yang dicapai siswa dalam proses kegiatan belajar mengajar dengan membawa suatu perubahan dan pembentukan tingkah laku seseorang. Untuk menyatakan bahwa suatu proses belajar dapat dikatakan berhasil, setiap guru memiliki pandangan masing-masing sejalan dengan filsafatnya. Namun untuk menyamakan persepsi sebaiknya kita berpedoman pada kurikulum yang berlaku saat ini yang telah disempurnakan, antara lain bahwa suatu proses belajar mengajar tentang suatu bahan pembelajaran dinyatakan berhasil apabila tujuan pembelajaran khususnya dapat dicapai.

Dalam rangka mengetahui tercapai tidaknya tujuan pembelajaran khusus, guru perlu mengadakan tes formatif pada setiap menyajikan suatu bahasan kepada siswa. Penilaian formatif ini untuk mengetahui sejauh mana siswa telah menguasai tujuan pembelajaran khusus yang ingin dicapai. Fungsi penelitian ini adalah untuk memberikan umpan balik pada guru dalam rangka memperbaiki proses belajar mengajar dan melaksanakan program remedial bagi siswa yang belum berhasil. Karena itulah, suatu proses belajar mengajar dinyatakan berhasil apabila hasilnya memenuhi tujuan pembelajaran khusus dari bahan tersebut.

Hasil belajar yang dicapai oleh siswa di sekolah merupakan salah satu ukuran terhadap penguasaan materi pelajaran yang disampaikan. Peran guru dalam menyampaikan materi pelajaran dapat mempengaruhi hasil belajar siswa. Faktor-faktor yang mempengaruhi hasil belajar siswa penting sekali untuk diketahui, artinya dalam rangka membantu siswa mencapai hasil belajar yang seoptimal mungkin. Hasil belajar akan semakin maksimal jika semua unsur masyarakat menyadari pentingnya pendidikan, karena pendidikan cara perbaik memperbarui kualitas bangsa (Tho'in, 2017).

Hasil belajar yang dicapai siswa dipengaruhi oleh dua faktor baik yang bersifat mendorong atau menghambat, demikian pula dalam belajar. Faktor yang mempengaruhi prestasi atau hasil belajar siswa yakni faktor dari dalam diri siswa (interen) dan faktor yang datang dari luar (eksteren). Ahmadi (1998:72) mengemukakan untuk mencapai prestasi belajar siswa sebagaimana yang diharapkan, maka perlu diperhatikan beberapa faktor yang mempengaruhinya antara lain faktor yang terdapat dalam diri siswa (faktor intern) dan faktor yang berasal dari luar diri siswa (faktor ekstern). 


\section{Bimbingan dan Konseling (BK)}

Bimbingan dan Konseling (BK) adalah proses interaksi antara konselordengan konseli baik secara langsung maupun tidak langsung dalam rangka untuk membantu konseli agar dapat mengembangkan potensi dirinya atau pun memecahkan permasalahan yang dialaminya (Wikipedia Bahasa Indonesia).

Menurut Abu Ahmadi (1991: 1), bahwa bimbingan adalah bantuan yang diberikan kepada individu (peserta didik) agar dengan potensi yang dimiliki mampu mengembangkan diri secara optimal dengan jalan memahami diri, memahami lingkungan, mengatasi hambatan guna menentukan rencana masa depan yang lebih baik. Hal senada juga dikemukakan oleh Prayitno dan Erman Amti (2004: 99), Bimbingan adalah proses pemberian bantuan yang dilakukan oleh orang yang ahli kepada seseorang atau beberapa orang individu, baik anak-anak, remaja, atau orang dewasa; agar orang yang dibimbing dapat mengembangkan kemampuan dirinya sendiri dan mandiri dengan memanfaatkan kekuatan individu dan sarana yang ada dan dapat dikembangkan berdasarkan norma-norma yang berlaku.

Sementara Bimo Walgito (2004: 4-5), mendefinisikan bahwa bimbingan adalah bantuan atau pertolongan yang diberikan kepada individu atau sekumpulan individu dalam menghindari atau mengatasi kesulitan-kesulitan hidupnya, agar individu dapat mencapai kesejahteraan dalam kehidupannya. Chiskolm dalam McDaniel, dalam Prayitno dan Erman Amti (1994: 94), mengungkapkan bahwa bimbingan diadakan dalam rangka membantu setiap individu untuk lebih mengenali berbagai informasi tentang dirinya sendiri.

Konseling adalah hubungan pribadi yang dilakukan secara tatap muka antarab dua orang dalam mana konselor melalui hubungan itu dengan kemampuan-kemampuan khusus yang dimilikinya, menyediakan situasi belajar. Dalam hal ini konseli dibantu untuk memahami diri sendiri, keadaannya sekarang, dan kemungkinan keadaannya masa depan yang dapat ia ciptakan dengan menggunakan potensi yang dimilikinya, demi untuk kesejahteraan pribadi maupun masyarakat. Lebih lanjut konseli dapat belajar bagaimana memecahkan masalah-masalah dan menemukan kebutuhan-kebutuhan yang akan datang. (Tolbert, dalam Prayitno 2004 : 101).

Jones (Insano, 2004: 11) menyebutkan bahwa konseling merupakan suatu hubungan profesional antara seorang konselor yang terlatih dengan klien. Hubungan ini biasanya bersifat individual atau seorang-seorang, meskipun kadang-kadang melibatkan lebih dari dua orang dan dirancang untuk membantu klien memahami dan memperjelas pandangan terhadap ruang lingkup hidupnya, sehingga dapat membuat pilihan yang bermakna bagi dirinya.

Jadi dapat disimpulkan bahwa pengertian bimbingan dan konseling yaitu suatu bantuan yang diberikan oleh konselor kepada konseli agar konseli mampu menyelesaikan masalah yang dihadapinya dan juga mampu mengembangkan potensi yang dimilikinya.

a. Tujuan bimbingan dan konseling yang terkait dengan aspek pribadi-sosial konseli adalah: Pertama, memiliki komitmen yang kuat dalam mengamalkan nilai-nilai keimanan dan ketaqwaan kepada Tuhan Yang Maha Esa, baik dalam kehidupan pribadi, keluarga, pergaulan dengan teman sebaya, Sekolah/Madrasah, tempat kerja, maupun masyarakat 
pada umumnya. Kedua, memiliki sikap toleransi terhadap umat beragama lain, dengan saling menghormati dan memelihara hak dan kewajibannya masing-masing. Ketiga, memiliki pemahaman tentang irama kehidupan yang bersifat fluktuatif antara yang menyenangkan (anugrah) dan yang tidak menyenangkan (musibah), sertadan mampu meresponnya secara positif sesuai dengan ajaran agama yang dianut. Keempat, memiliki pemahaman dan penerimaan diri secara objektif dan konstruktif, baik yang terkait dengan keunggulan maupun kelemahan; baik fisik maupun psikis. Kelima, memiliki sikap positif atau respek terhadap diri sendiri dan orang lain. Keenam, memiliki kemampuan untuk melakukan pilihan secara sehat. Ketujuh, bersikap respek terhadap orang lain, menghormati atau menghargai orang lain, tidak melecehkan martabat atau harga dirinya. Memiliki rasa tanggung jawab, yang diwujudkan dalam bentuk komitmen terhadap tugas atau kewajibannya. Kedelapan, memiliki kemampuan berinteraksi sosial (human relationship), yang diwujudkan dalam bentuk hubungan persahabatan, persaudaraan, atau silaturahim dengan sesama manusia. Kesembilan, memiliki kemampuan dalam menyelesaikan konflik (masalah) baik bersifat internal (dalam diri sendiri) maupun dengan orang lain. Kesepuluh, memiliki kemampuan untuk mengambil keputusan secara efektif.

b. Tujuan bimbingan dan konseling yang terkait dengan aspek akademik (belajar) adalah: Pertama, memiliki kesadaran tentang potensi diri dalam aspek belajar, dan memahami berbagai hambatan yang mungkin muncul dalam proses belajar yang dialaminya. Kedua, memiliki sikap dan kebiasaan belajar yang positif, seperti kebiasaan membaca buku, disiplin dalam belajar, mempunyai perhatian terhadap semua pelajaran, dan aktif mengikuti semua kegiatan belajar yang diprogramkan. Ketiga, memiliki motif yang tinggi untuk belajar sepanjang hayat. Keempat, memiliki keterampilan atau teknik belajar yang efektif, seperti keterampilan membaca buku, mengggunakan kamus, mencatat pelajaran, dan mempersiapkan diri menghadapi ujian. Kelima, memiliki keterampilan untuk menetapkan tujuan dan perencanaan pendidikan, seperti membuat jadwal belajar, mengerjakan tugas-tugas, memantapkan diri dalam memperdalam pelajaran tertentu, dan berusaha memperoleh informasi tentang berbagai hal dalam rangka mengembangkan wawasan yang lebih luas. Keenam, memiliki kesiapan mental dan kemampuan untuk menghadapi ujian.

c. Tujuan bimbingan dan konseling yang terkait dengan aspek karir adalah: Pertama, memiliki pemahaman diri (kemampuan, minat dan kepribadian) yang terkait dengan pekerjaan. Kedua, memiliki pengetahuan mengenai dunia kerja dan informasi karir yang menunjang kematangan kompetensi karir. Ketiga, memiliki sikap positif terhadap dunia kerja. Dalam arti mau bekerja dalam bidang pekerjaan apapun, tanpa merasa rendah diri, asal bermakna bagi dirinya, dan sesuai dengan norma agama. Keempat, memahami relevansi kompetensi belajar (kemampuan menguasai pelajaran) dengan persyaratan keahlian atau keterampilan bidang pekerjaan yang menjadi cita-cita karirnya masa depan. Kelima, memiliki kemampuan untuk membentuk identitas karir, dengan cara mengenali ciri-ciri pekerjaan, kemampuan (persyaratan) yang dituntut, lingkungan sosiopsikologis pekerjaan, prospek kerja, dan kesejahteraan kerja. Keenam, memiliki kemampuan 
merencanakan masa depan, yaitu merancang kehidupan secara rasional untuk memperoleh peran-peran yang sesuai dengan minat, kemampuan, dan kondisi kehidupan sosial ekonomi. Ketujuh, dapat membentuk pola-pola karir, yaitu kecenderungan arah karir. Apabila seorang konseli bercita-cita menjadi seorang guru, maka dia senantiasa harus mengarahkan dirinya kepada kegiatan-kegiatan yang relevan dengan karir keguruan tersebut. Kedelapan, mengenal keterampilan, kemampuan dan minat. Keberhasilan atau kenyamanan dalam suatu karir amat dipengaruhi oleh kemampuan dan minat yang dimiliki.

Fungsi Bimbingan Konseling

a. Fungsi Pemahaman, yaitu fungsi bimbingan dan konseling membantu konseli agar memiliki pemahaman terhadap dirinya (potensinya) dan lingkungannya (pendidikan, pekerjaan, dan norma agama). Berdasarkan pemahaman ini, konseli diharapkan mampu mengembangkan potensi dirinya secara optimal, dan menyesuaikan dirinya dengan lingkungan secara dinamis dan konstruktif.

b. Fungsi Preventif, yaitu fungsi yang berkaitan dengan upaya konselor untuk senantiasa mengantisipasi berbagai masalah yang mungkin terjadi dan berupaya untuk mencegahnya, supaya tidak dialami oleh konseli. Melalui fungsi ini, konselor memberikan bimbingan kepada konseli tentang cara menghindarkan diri dari perbuatan atau kegiatan yang membahayakan dirinya.

c. Fungsi Pengembangan, yaitu fungsi bimbingan dan konseling yang sifatnya lebih proaktif dari fungsi-fungsi lainnya. Konselor senantiasa berupaya untuk menciptakan lingkungan belajar yang kondusif, yang memfasilitasi perkembangan konseli. Konselor dan personel Sekolah/Madrasah lainnya secara sinergi sebagai teamwork berkolaborasi atau bekerjasama merencanakan dan melaksanakan program bimbingan secara sistematis dan berkesinambungan dalam upaya membantu konseli mencapai tugas-tugas perkembangannya. Teknik bimbingan yang dapat digunakan disini adalah pelayanan informasi, tutorial, diskusi kelompok atau curah pendapat (brain storming), home room, dan karyawisata.

d. Fungsi Penyembuhan, yaitu fungsi bimbingan dan konseling yang bersifat kuratif. Fungsi ini berkaitan erat dengan upaya pemberian bantuan kepada konseli yang telah mengalami masalah, baik menyangkut aspek pribadi, sosial, belajar, maupun karir. Teknik yang dapat digunakan adalah konseling, dan remedial teaching.

e. Fungsi Penyaluran, yaitu fungsi bimbingan dan konseling dalam membantu konseli memilih kegiatan ekstrakurikuler, jurusan atau program studi, dan memantapkan penguasaan karir atau jabatan yang sesuai dengan minat, bakat, keahlian dan ciri-ciri kepribadian lainnya. Dalam melaksanakan fungsi ini, konselor perlu bekerja sama dengan pendidik lainnya di dalam maupun di luar lembaga pendidikan.

f. Fungsi Adaptasi, yaitu fungsi membantu para pelaksana pendidikan, kepala Sekolah/Madrasah dan staf, konselor, dan guru untuk menyesuaikan program pendidikan terhadap latar belakang pendidikan, minat, kemampuan, dan kebutuhan konseli. Dengan menggunakan informasi yang memadai mengenai konseli, pembimbing/konselor dapat membantu para guru dalam memperlakukan konseli secara tepat, baik dalam memilih dan 
menyusun materi Sekolah/Madrasah, memilih metode dan proses pembelajaran, maupun menyusun bahan pelajaran sesuai dengan kemampuan dan kecepatan konseli.

g. Fungsi Penyesuaian, yaitu fungsi bimbingan dan konseling dalam membantu konseli agar dapat menyesuaikan diri dengan diri dan lingkungannya secara dinamis dan konstruktif.

h. Fungsi Perbaikan, yaitu fungsi bimbingan dan konseling untuk membantu konseli sehingga dapat memperbaiki kekeliruan dalam berfikir, berperasaan dan bertindak (berkehendak). Konselor melakukan intervensi (memberikan perlakuan) terhadap konseli supaya memiliki pola berfikir yang sehat, rasional dan memiliki perasaan yang tepat sehingga dapat mengantarkan mereka kepada tindakan atau kehendak yang produktif dan normatif.

i. Fungsi Fasilitasi, memberikan kemudahan kepada konseli dalam mencapai pertumbuhan dan perkembangan yang optimal, serasi, selaras dan seimbang seluruh aspek dalam diri konseli.

j. Fungsi Pemeliharaan, yaitu fungsi bimbingan dan konseling untuk membantu konseli supaya dapat menjaga diri dan mempertahankan situasi kondusif yang telah tercipta dalam dirinya. Fungsi ini memfasilitasi konseli agar terhindar dari kondisi-kondisi yang akan menyebabkan penurunan produktivitas diri. Pelaksanaan fungsi ini diwujudkan melalui program-program yang menarik, rekreatif dan fakultatif (pilihan) sesuai dengan minat konseli.

\section{Metode Role Play}

Role playing atau bermain peran adalah sejenis permainan gerak yang didalamnya ada tujuan, aturan dan sekaligus melibatkan unsur senang (Jill Hadfield, 1986). Dalam role playing murid dikondisikan pada situasi tertentu di luar kelas, meskipun saat itu pembelajaran terjadi di dalam kelas. Selain itu, role playing sering kali dimaksudkan sebagai suatu bentuk aktivitas dimana pembelajar membayangkan dirinya seolah-olah berada di luar kelas dan memainkan peran orang lain (Basri Syamsu, 2000).

Metode Role Playing adalah suatu cara penguasaan bahan-bahan pelajaran melalui pengembangan imajinasi dan penghayatan siswa. Pengembangan imajinasi dan penghayatan dilakukan siswa dengan memerankannya sebagai tokoh hidup atau benda mati. Permainan ini pada umumnya dilakukan lebih dari satu orang, hal itu bergantung kepada apa yang diperankan. Pada metode bermain peranan, titik tekanannya terletak pada keterlibatan emosional dan pengamatan indera ke dalam suatu situasi masalah yang secara nyata dihadapi. Murid diperlakukan sebagai subyek pembelajaran, secara aktif melakukan praktikpraktik berbahasa (bertanya dan menjawab) bersama teman-temannya pada situasi tertentu. Belajar efektif dimulai dari lingkungan yang berpusat pada diri murid (Departemen Pendidikan Nasional, 2002). Lebih lanjut prinsip pembelajaran memahami kebebasan berorganisasi, dan menghargai keputusan bersama, murid akan lebih berhasil jika mereka diberi kesempatan memainkan peran dalam bermusyawarah, melakukan pemungutan suara terbanyak dan bersikap mau menerima kekalahan sehingga dengan melakukan berbagai kegiatan tersebut dan secara aktif berpartisipasi, mereka akan lebih mudah menguasai apa 
yang mereka pelajari (Boediono, 2001). Jadi, dalam pembelajaran murid harus aktif, karena tanpa adanya aktivitas, maka proses pembelajaran tidak mungkin terjadi.

Penggunaan metode role playing atau bermain peran, memiliki beberapa kelebihan, yaitu sebagai berikut. Pertama, permainan yang diperankan sendiri, membantu dalam memahami masalah-masalah yang sedang dihadapi (Santoso, 2010). Kedua, bagi peserta yang memainkan peran sebagai orang lain, maka peserta tersebut dapat menempatkan dirinya sendiri seperti watak dari karakter yang dimainkan itu (Satoso, 2010). Ketiga, mampu merasakan perasaan yang dialami oleh orang lain. Hal tersebut mampu menumbuhkan sikap saling memperhatikan orang lain (Santoso, 2010).

Selain memiliki beberapa kelebihan, metode role playing atau bermain peran juga memiliki beberapa kekurangan, yaitu sebagai berikut. Pertama, apabila pelatih tidak menguasai metode bermain peran dalam setiap sesi yang diadakan dalam pelatihan, maka akan menjadikan metode bermain peran ini menjadi tidak berhasil (Santoso, 2010). Kedua, langkah-langkah dalam metode bermain peran yang tidak dipahami trainer dengan baik, dapat menimbulkan kekacauan selama kegiatan berlangsung (Santoso, 2010).

Ternyata dalam metode role playing ini akan menjadi suatu kelemahan, ketika guru atau pembimbing atau pelatih tidak memahami dengan baik, tentang langkah-langkah dalam melasanakan metode role playing. Pembahasan yang selanjutnya akan memberikan penjelasan tentang langkah langkah dalam role playing yang perlu dilakukan oleh guru. Sebagai pembanding penting juga untuk mempelajari Metode Simulasi, jadi pelajari juga metode tersebut.

Adapun langkah-langkah yang perlu dilakukan oleh guru, ketika menerapkan metode pembelajaran dengan menggunakan teknik bermain peran. Langkah-langkah tersebut (Wicaksono dkk. 2016) dapat dijelaskan sebagai berikut.

a. Guru atau pembimbing perlu untuk menyusun atau menyiapkan tentang skenario yang akan ditampilkan di kelas.

b. Guru membentuk siswa dalam kelompok-kelompok.

c. Guru memberikan penjelasan pada siswa tentang kompetensi-kompetensi yang ingin dicapai melalui kegiatan pembelajaran role playing.

d. Kemudian, guru memanggil siswa yang telah ditunjuk untuk memainkan peran sesuai dengan skenario yang telah disiapkan oleh guru.

e. Masing-masing siswa berada dalam kelompoknya, kemudian siswa tersebut melakukan pengamatan pada siswa yang sedang memperagaka skenarionya.

f. Guru meminta masing-masing kelompok untuk menyusun dan menyampaikan hasil kesimpulan berdasarkan skenario yang dimainkan oleh kelompok yang lain.

g. Pada langkah terakhir ini, guru memberikan kesimpulan dari kegiatan role playing yang dilakukan bersama siswa. Kesimpulan yang diberikan guru bersifat umum.

Penjelasan di atas menunjukkan bahwa ada tujuh langkah yang harus dilakukan oleh guru, ketika menerapkan suatu teknik bermain peran dalam kegiatan pembelajaran. Skenario sebagai bagian yang penting dalam bermain peran perlu disusun oleh guru dengan cara sebaik mungkin. 
Sama hal nya dengan metode-metode pembelajaran dengan teknik yang lain, metode role playing atau bermain peran, juga memiliki tujuan. Tujuan dari metode role playing atau bermain peran, yaitu mengajarkan tentang empati pada siswa (Ismail, 1998). Siswa diajak untuk mengalami dunia dengan cara melihat dari sudut pandang orang lain. Siswa diminta untuk membayangkan dirinya di posisi orang lain agar bisa menyelami perasaan dan sikap yang tunjukkan oleh orang lain, memahami dan peduli terhadap tujuan dan perjuang dari orang lain, dan mencoba untuk berperan yang tidak biasa. Dalam artian memainkan peran orang lain yang mungkin dapat berbeda dengan karakteristik yang ada dalam dirinya.

\section{METODE}

Metode penelitian menggunakan penelitian tindakan kelas (PTK) yang dilaksanakan dalam dua siklus setiap siklus terdiri dua kali pertemuan, dengan empat tahap penelitian: perencanaan, pelaksanaan, pengamatan dan refleksi. Subjek penelitian ini adalah siswa-siswi kelas VII E SMP Negeri 7 Sukoharjo tahun ajaran 2017/2018. Dengan jumlah 30 siswa. Teknik pengumpulan data yang digunakan adalah observasi, wawancara, tes, dan dokumentasi. Analisis data yang digunakan dalam penelitian ini adalah analisis deskriptif kualitatif.

\section{PEMBAHASAN}

Setelah peneliti melaksanakn tindakan penelitian melalui penerapan metode role play, secara empiris diperoleh data peningkatan prestasi belajar bimbingan dan konseling (BK) materi peningkatan pemahaman tentang motivasi belajar siswa kelas VII E SMP Negeri 7 Sukoharjo Kecamatan Sukoharjo, Kabupaten Sukoharjo Semester I Tahun Pelajaran 2017/2018 dari kondisi awal, siklus I dan siklus II sebagai berikut.

Tabel 1. Peningkatan Prestasi Belajar Siswa

\begin{tabular}{|l|c|c|c|}
\hline Uraian & Kondisi awal & Siklus I & Siklus II \\
\hline $\begin{array}{c}\text { Tindakan } \\
\text { Pembelajaran }\end{array}$ & $\begin{array}{c}\text { Belum menerapkan } \\
\text { metode role play }\end{array}$ & $\begin{array}{c}\text { Sudah menerapkan } \\
\text { metode role play }\end{array}$ & $\begin{array}{c}\text { Sudah menerapkan } \\
\text { metode role play }\end{array}$ \\
\hline Nilai terendah & 60 & 60 & 70 \\
Nilai tertinggi & 80 & 90 & 90 \\
Nilai rata-rata & 70 & 75 & 85 \\
KKM & 75 & 75 & 75 \\
Ketuntasan & 18 siswa $(60 \%)$ & 22 siswa $(73,33 \%)$ & 27 siswa (90\%) \\
\hline
\end{tabular}

Melalui penerapan metode role play dapat meningkatkan prestasi belajar bimbingan dan konseling (BK) materi peningkatan pemahaman tentang motivasi belajar. Pada kondisi awal peneliti belum menerapkan metode role play. Nilai rata-rata siswa kelas VII E adalah 70, masih di bawah nilai KKM yang ditetapkan yaitu 75 . Nilai tertinggi siswa 80, nilai terendah 60 dan jumlah siswa kelas VII E yang mencapai nilai KKM hanya 18 siswa (60\%) dari total 30 siswa kelas VII E SMP Negeri 7 Sukoharjo. 
Pada siklus I guru peneliti sudah menerapkan metode role play dalam pembelajaran bimbingan dan konseling (BK) materi peningkatan pemahaman tentang motivasi belajar. Nilai rata-rata prestasi belajar bimbingan dan konseling (BK) materi peningkatan pemahaman tentang motivasi belajar siswa kelas VII E SMP Negeri 7 Sukoharjo adalah 75, nilai tertinggi 90 dan nilai terendah adalah 60. Sedangkan jumlah siswa yang mencapai nilai KKM sebanyak 22 siswa (73,33\%) dari total 30 siswa kelas VII E SMP Negeri 7 Sukoharjo.

Pada siklus II, nilai rata-rata prestasi belajar bimbingan dan konseling (BK) materi peningkatan pemahaman tentang motivasi belajar siswa kelas VII E SMP Negeri 7 Sukoharjo adalah 85, nilai tertinggi 90 dan nilai terendah 70. Jumlah siswa yang mencapai nilai KKM sebanyak 27 siswa (90\%) dari total 30 siswa kelas VII E SMP Negeri 7 Sukoharjo.

Jadi, melalui penerapan metode role play dapat meningkatkan prestasi belajar bimbingan dan konseling (BK) materi peningkatan pemahaman tentang motivasi belajar dari kondisi awal nilai rata-rata 70 dengan ketuntasan $60 \%$ ke kondisi akhir pada siklus II nilai rata-rata 85 dengan ketuntasan 90\% pada siswa kelas VII E SMP Negeri 7 Sukoharjo semester I Tahun Pelajaran 2017/2018.

Hasil tindakan secara empirik yaitu: melalui penerapan metode role play dapat meningkatkan prestasi belajar bimbingan dan konseling (BK) materi peningkatan pemahaman tentang motivasi belajar dari kondisi awal nilai rata-rata 70 dengan ketuntasan $60 \%$ ke kondisi akhir pada siklus II nilai rata-rata 85 dengan ketuntasan $90 \%$ pada siswa kelas VII E SMP Negeri 7 Sukoharjo Semester I Tahun Pelajaran 2017/2018.

\section{SIMPULAN}

Hipotesis menyatakan diduga melalui penerapan motode pembelajaran role play dapat meningkatkan hasil belajar bimbingan dan konseling (BK) materi peningkatan pemahaman tentang motivasi belajar pada siswa kelas VII E SMP Negeri 7 Sukoharjo Semester I Tahun Pelajaran 2017/2018. Dari data empirik menyatakan melalui penerapan motode pembelajaran role play dapat meningkatkan hasil belajar bimbingan dan konseling (BK) materi peningkatan pemahaman tentang motivasi belajar dari kondisi awal nilai rata-rata 70 dengan ketuntasan $60 \%$ ke kondisi akhir pada siklus II nilai rata-rata 85 dengan ketuntasan 90\% pada siswa kelas VII E SMP Negeri 7 Sukoharjo Semester I Tahun Pelajaran 2017/2018. Sehingga dapat disimpulkan bahwa melalui penerapan motode pembelajaran role play dapat meningkatkan hasil belajar bimbingan dan konseling (BK) materi peningkatan pemahaman tentang motivasi belajar pada siswa kelas VII E SMP Negeri 7 Sukoharjo semester I Tahun Pelajaran 2017/2018.

\section{DAFTAR PUSTAKA}

Abu Ahmadi. (1991). Psikologi Belajar. Jakarta. PT Rineka Cipta

Ahmadi, Abu. 1998. Psikologo Pendidikan. Jakarta : Rineka Cipta

A.M. Sardiman (2005). Interaksi dan Motivasi Belajar Mengajar. Jakarta: Rajawali Press. 
Basri, Syamsu. 2000. Teaching speaking. Makalah disampaikan pada Penataran Instruktur Guru Bahasa Inggris SLTP Swasta tanggal 8 - 19 Pebruari 2000 di Jakarta

Bimo Walgito. (2004). Pengantar psikologi Umum. Jakarta: Penerbit Andi

Departemen Pendidikan Nasional. 2002. Belajar Efektif Dimulai Dari Lingkungan Yang Berpusat Pada Diri Murid.

Dimyati dan Mudjiono. 2006. Belajar dan Pembelajaran. Jakarta: Rineka Cipta

Ismail, 1998, “ Kapita Selekta Pendidikan Matematika “, ( Jakarta : Universitas Terbuka)

Jill Hadfield (1986). Classroom Dynamic. Oxford University Press.

Kamus Besar Bahasa Indonesia (2001). Pengertian Motivasi.

Moh. Surya. 1981. Psikologi Pembelajaran dan Pengajaran. Bandung. PPB - IKIP Bandung.

M. Sobry Sutikno. 2010. Strategi Belajar Mengajar Melalui Penanaman Konsep Umum \& Konsep Islami. Refika Aditama: Bandung.

Nasution. 1995. Metode Research. Jakarta: PT. Bumi Aksara

Ngalim Purwanto. 1986. Psikologi Pendidikan. Bandung: PT Remaja Rosdakarya.

Oemar Hamalik,. (2003). Proses Belajar Mengajar. Jakarta: PT. Bumi Aksara.

Prayitno. 2004. Layanan Bimbingan Kelompok Dan Konseling Kelompok. Padang: Universitas Negeri Padang.

Prayitno dan Amti, Erman. 2004. Dasar-Dasar Bimbingan dan Konseling. Jakarta: Rineka Cipta.

Santoso. 2010. Teori-Teori Psikologi Sosial. Bandung: Refika Aditama.

Slameto. 2000. Belajar dan Faktor-faktor yang mempengaruhinya. Rineka Cipta,Jakarta

Sumarni, Siti. (2005). Pengertian Motivasi Belajar. http:// belajarpsikologi.com/ pengertianmotivasi-belajar/. 7 Desember2017@20.03 WIB.

Tho'in, M. (2017). Pembiayaan Pendidikan Melalui Sektor Zakat. Al-Amwal: Jurnal Ekonomi dan Perbankan Syari'ah, 9(2).

Thomas L. Good dan Jere B. Braphy .1986. diakses melalui url: http://belajarpsikologi.com/pengertian-motivasibelajar/ 31 Desember 2017

Winkel, W. S. 2004. Psikologi Pendidikan dan Evaluasi Belajar. Jakarta: PT. Gramedia Pustaka Utama. 